M.I. Stupnik, V.0. Kalinichenko, V.0. Kolosov, I. Bah, V. Pozdniakov

\title{
KEY ASPECTS OF THE FORMATION OF UNDERGROUND POINTS FOR MAINTENANCE AND REFUELING OF MINING SELF-PROPELLED EQUIPMENT
}

Due to the widespread introduction of self-propelled mining equipment at Kryvbass mines advised versions of underground service points and mining equipment refueling are proposed. The main directions of the proposed options are increasing safety during maintenance of mining machines, as well as a decreasing in fire hazard at refueling machines at underground conditions.

\section{ОСНОВНІ АСПЕКТИ ФОРМУВАННЯ ПІДЗЕМНИХ ПУНКТІВ ОБСЛУГОВУВАННЯ І ЗАПРАВЛЯННЯ ГІРНИЧОШАХТНОГО САМОХІДНОГО ОБЛАДНАННЯ}

у зв'язку з широким впровадженням на шахтах Кривбасу самохідного гірничого обладнання запропоновані вдосконалені варіанти підземних пунктів обслуговування та заправляння гірничошахтної техніки. Головними аспектами впровадження запропонованих варіантів є підвищення безпеки при обслуговуванні гірничих машин, а також зменшення пожежонебезпеки при заправлянні машин у підземних умовах.

\section{ОСНОВНЫЕ АСПЕКТЫ ФОРМИРОВАНИЯ ПОДЗЕМНЫХ ПУНКТОВ ОБСЛУЖИВАНИЯ И ЗАПРАВКИ ГОРНОШАХТНОГО САМОХОДНОГО ОБОРУДОВАНИЯ}

В связи с широким внедрением на шахтах Кривбасса самоходного горного оборудования предложены усовершенствованные варианты подземных пунктов обслуживания и заправки горношахтной техники. Основными аспектами внедрения предложенных вариантов являются повышение безопасности при обслуживании горных машин, а также уменьшение пожароопасности при заправке машин в подземных условиях.

THE PROBLEM AND ITS CONNECTION WITH SCIENTIFIC AND PRACTICAL TASKS

Self-propelled equipment has been used since 50-ies of XX century in underground mining abroad. These machines come to our country with a delay especially to iron ores mines $[1-3]$. One of the disadvantages of self-propelled underground transport is its flammability. Not only the diesel machines, but also workshops for maintenance of under- ground mining machines, underground storage of petroleum products and gas stations are certain danger in this respect. Consequently, the organization of such underground facilities is the actual scientific and practical problem requiring decision of various complex of technical problems. 


\section{PROBLEM STATEMENT}

The objective of this work is to develop advanced versions of underground service points and Mining Equipment refueling that will allow improving safety at maintenance of mining machines and reducing the fire hazard at refueling machines at underground conditions.

\section{MATERIAL PRESENTATION AND RESULTS}

Maintenance at the mine involves a range of required works to maintain serviceability or availability of mining machines, mining equipment transferred to the mines has a large mass and dimensions. They are delivered from the factory disassembled and some units are collected at underground conditions. It is necessary to conduct complex installation works at special underground service areas for their setting to operation.

Equipment before descending into the mine passes control assembly and testing is used. The main method for the control assembly is to simulate all actions. At that connection of all the elements must be securely fastened, the compounds of the drainage system and hydraulic equipment and hydraulic components must be tight.

All noticed faults at the control assembly on the surface and testing must be corrected before the descent of equipment into the mine.

Equipment comes to the mine in assembly units transportable at underground conditions. Loaders, before descending into the mine are dissociated into individual units and sections. Final assembly of the self-propelled mining equipment is carried out at special underground service areas. Assembled selfpropelled mining machines move under its power through underground workings to the stope.

Special attention is paid to safety of underground refueling stations. The authors suggest advanced versions of underground fueling stations, which can be used at the mines of the Kryvyi Rih basin and other do- mestic or foreign mines.

Underground refueling station for selfpropelled equipment includes chambers for filling machines and parking of mobile vessels connected to the haulage road, pass connecting chambers, vent revolting, communication devices and fuel-oil service for firefighting equipment unit. Chamber for filling machines and parking mobile vessels made deadlocked, located at the runaway of the of haulage horizon at the self-propelled equipment concentration. There is a cutout for fueloil devices and sump for draining the used oil in the dead-end chamber for filling machines. Dispensers mounted on the wall niches and are connected directly to the mobile communications tanks located in a dead-end chamber.

Figure 1 shows an underground refueling station for self-propelled equipment. It includes dead-end chamber 1 (Fig. 1) for parking of mobile tanks of fuel and lubricants (FL), communicating with the haulage road, mobile tanks 2 fuel, 3 ventilation revolting, 4 fuel-oil assembly trench, 5 pass with communications connecting both chambers of the item and fire doors 6 . Chamber 7 used for refueling vehicles. At the niche of a wall 8 fueloil devices and pit 9 sump for draining the used oil. At the niche 10 fire fighting resources are located. Runaway 11 is for workers and haulage horizons as a connecting shaft. Fire belt 12 make of two metal doors each. To filling station crosscut 13 is adjacent serving for connecting haulage way 14 with ramps from mine floor.

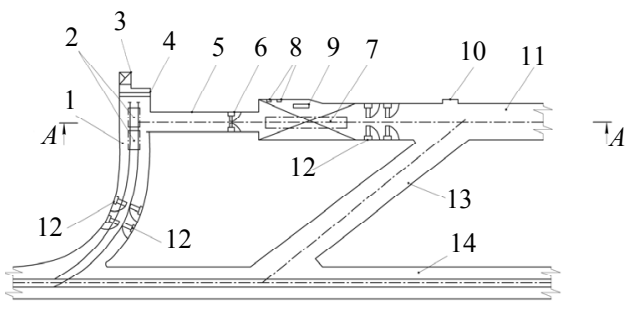

Fig. 1. Underground refueling point for self-propelled equipment 
On mine floor 15 (Fig. 2) self-propelled machines 16 are shown.

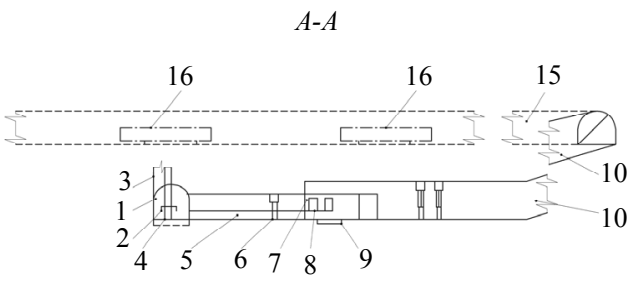

Fig. 2. Combined vertical projection of the main haulage horizon and underground refueling point

Petrol station is used as follows. Selfpropelled machine goes off the mine floor on ramps, falling directly into the camera for refueling. In a gas chamber operator using the wall manual or mechanical pump pumps the fuel and lubricants from mobile containers into suitable containers of machines. If it is necessary to replace the oil it is drained from the tanks machine into portable containers located in the pit 9. After refueling, selfpropelled machine on ramps travels the shortest path on the mine floor to the workplace.

There is another possible embodiment of the underground refueling point for selfpropelled equipment. Its essence lies in the fact that the underground section blind chamber for filling machines and parking mobile vessels arranged in parallel between a haulageway in the concentration of self-propelled equipment are made. In the dead-end chamber for filling machines also niche is passed under fuel lubricant refuelers and sump to drain the used oil. The dispenser device, in this case, is attached to the niche wall and connected directly by communications with mobile containers disposed in the blind chamber.

Petrol station in the second embodiment is used in cases where no ramps from mine floor to haulage way and works as in the first embodiment, except that porches for selfpropelled vehicles cross haulage way.

\section{CONCLUSIONS}

Variants of underground service points and refueling of mining equipment that allow improving safety in servicing mining machines and reduce the fire hazard when fueling of self-propelled diesel equipment in underground conditions are developed. Underground points were designed as separate, unrelated between salable of blind chambers that connected to the vent raise and have driveways during sealed metal doors are proposed. These measures will improve labour efficiency at mining equipment maintenance, reduce fire risk and improve the overall safety of mining.

\section{REFERENCES}

1. Байконуров О.А. Комплексная механизация подземной разрабоки руд / О.А. Байконуров, А.Т. Филимонов, С.Г. Калошин. - М.: Недра, 1981. - 264 с.

2. Кулешов А.А. Самоходный транспорт для подземных горных работ / А.А. Кулешов, В.А. Фокин. - СПб.: Санкт-Петербургский горный институт, 1999. - 102 c.

3. Ступнік M.І. Стан і перспективи розвитку підземних гірничих робіт у Криворізькому басейні / M.I. Ступнік, В.О. Колосов, В.О. Калініченко // Розробка родовищ: щоріч. наук.-техн. 36. - Д.: ТОВ «ЛізуновПрес», 2013. C. $223-228$.

\section{ABOUT AUTHORS}

Stupnik Mykola Ivanovych - Doctor of Engineering, professor of Underground Mining Department, Ag. of rector of Kryvorizskyi National University.

Kalinichenko Vsevolod Oleksandrovych - Doctor of Engineering, professor of Underground Mining Department. 
Kolosov Valerii Oleksandrovych - Doctor of Engineering, Chief of managing executive committee of association "Ukrrudprom".

Bah Ibragim - Dean of Faculty of University n.a. Gamalia Abdel Nasera (Conakry, Guinea).
Pozdniakov Valerii - professor-consultant of University n.a. Gamalia Abdel Nasera (Conakry, Guinea). 